\title{
PENGARUH PENATALAYANAN PERPUSTAKAAN TERHADAP TINGKAT FREKUENSI KUNJUNGAN MAHASISWA PRODI PENDIDIKAN AGAMA KRISTEN IAKN TARUTUNG
}

\author{
Herowati Sitorus \\ Institut Agama Kristen Tarutung \\ Email: sitorusherowati@yahoo.co.id
}

\begin{abstract}
Abstrak : Penelitian ini bertujuan untuk mengetahui pengaruh penatalayanan perpustakaan terhadap minat baca mahasiswa semester IV tahun ajaran 2018/2019 di IAKN Tarutung. Dengan hipotesis terdapat pengaruh yang positif dan signifikan antara penatalayanan perpustakaan dengan minat baca (sama dengan tingkat kunjungan) mahasiswa semester IV tahun ajaran 2018/2019 di IAKN Tarutung. Populasi penelitian berjumlah 207 orang dan sampel berjumlah 41 orang. Minat baca merupakan suatu kecenderungan kepemilikan keinginan atau ketertarikan yang kuat dan disertai usaha-usaha yang terus menerus pada diri seseorang terhadap kegiatan membaca yang dilakukan secara terusmenerus dan diikuti dengan rasa senang dan tanpa paksaan, atas kemauananya sendiri atau dorongan dari luar sehingga seseorang tersebut mengerti atau memahami apa yang dibacanya. Data dikumpulkan dengan angket tertutup sebanyak 30 item yang disusun peneliti berdasarkan indikator variabel sesuai dengan teori ahli. Uji coba instrumen dilakukan kepada 41 mahasiswa yang bukan responden penelitian, dan telah diuji validitas dan reablitasnya. Hasil analisis data menunjukkan bahwa terdapat pengaruh yang positif dan signifikan antara pengaruh penatalayanan perpustakaan terhadap tingkat kunjungan mahasiswa semester IV tahun ajaran 2018/2019 di IAKN Tarutung. Dengan uji Anava atau F test, dapat F dihitung adalah 22,778 dengan tingkat signifikan $0,000^{\mathrm{b}}<0,005$. Karena probabilitas $(0,000)$ lebih kecil dari 0,05 , artinya ada pengaruh positif dan signifikan antara Penatalayanan Perpustakaan dengan tingkat kunjungan.
\end{abstract}

Kata-kata Kunci: Penatalayanan, Tingkat Kunjungan

Abtract : This study was aimed to determine the effect of library stewardship on students' reading interest in the 2018/2019 academic year at IAKN Tarutung. After conducting randomly sampling, there were 41 students involving as participants in this study. Reading interest is a tendency to read continuously for having desires or interests. Data was collected by a closed questionnaire consisting of 30 items compiled by researchers based on variable indicators according to expert panels. The Instrument has validity and reliability which has tested. The results of data analysis showed that there was a positive and significant influence between the effect of library stewardship on the students' visit to the library of IAKN Tarutung. With ANOVA or F test, F can be calculated is 22.778 with a significant level of $0.000 \mathrm{~b}<0.005$. Due to the probability $(0.000)$ is smaller than 0.05 , it means that there is a positive and significant influence between library stewardship and students' visit level.

Keywords: Stewardship; students' visit level; library

\section{PENDAHULUAN}

Perpustakaan dalam pasal 1 ayat 1 Undang-Undang No. 43 Tahun 2007 didefenisikan sebagai, "institusi pengelola koleksi karya tulis, karya cetak, dan atau karya rekam secara professional dengan system yang baku guna memenuhi kebutuhan pendidikan, penelitian, pelestarian informasi dan rekreasi para pemustaka ${ }^{1}$. Sebagai sebuah institusi pengelola koleksi karya tulis, perpustakaan mengelola dan mengorganisir koleksinya yang

\footnotetext{
${ }^{1}$ Indonesia Undang-undang Republik Indonesia Nomor 43 Tahun 2007 tentang Perpustakaan, Bab I Pasal 1 , hal 2
}

terdiri dari berbagai jenis sumber daya informasi agar dapat diakses oleh komunitas penggunanya ${ }^{2}$. Perpustakaan menyediakan akses terhadap bahan-bahan perpustakaan yang menjadi sumber daya informasi, baik dalam format cetak maupun digital, sehingga wujud dari sebuah perpustakaan dapat berupa sebuah bangunan fisik (gedung atau ruangan ) atau ruangan virtual atau kombinasi dari keduanya.

$$
\text { Perpustakaan perguruan tinggi }
$$
merupakan unsur penunjang perguruan tinggi, yang bersama-sama dengan unsur penunjang

\footnotetext{
${ }^{2}$ Allen, R. E., ed. 1984. The Pocket Oxford Dictionary ofCurrentEnglish. Oxford:Clarendon Press. Hal421
} 
lainnya, berperan serta dalam melaksanakan tugas dan fungsinya untuk mencapai visi dan misi perguruan tinggi ${ }^{3}$. Kedudukan perpustakaan dalam organisasi perguruan tinggi dapat berbeda antara satu perguruan tinggi dengan lainnya. Buku pedoman perpustakaan perguruan tinggi ${ }^{4}$, menggambarkan struktur organisasi dan hubungan kerja perpustakaan adalah setara dengan fakultas, lembaga penelitian dan lembaga pengabdian kepada masyarakat. Akan tetapi dalam praktiknya, apa yang digambarkan dalam buku pedomana penyelenggaraan perpustakaan tersebut tidak selalu direalisasikan, hal itu sangat tergantung kepada statuta yang mengatur tata kelola sebuah perguruan tinggi dan sudut pandang sivitas akademika terhadap perpustakaan. Ada kalanya perpustakaan dipandang sebagai institusi strategis dalam kegiatan akademik dan penelitian, akan tetapi ada pula yang melihat posisi perpustakaan hanya sekedar unit pendukung teknis semata, bahkan ada yang memandang sebagai unit kerja yang sifatnya cost centre.

Bagi perguruan tinggi pada umumnya, perpustakaaan sampai saat ini tetap dipandang sebagai komponen utama dari system pendidikan tinggi (key components of higher education system). Penyelenggara perpustakaan sebagai sumber belajar merupakan suatu keharusan dan mempunyai peran yang sangat dalam pendidikan. Pendidikan tinggi tidak mungkin terselengara dengan baik jika para dosen dan mahasiswa tidak didukung oleh sumber belajar yang diperlukan untuk penyelenggaraan kegiatan belajar mengajar.

Perpustakaan tidak hanya menyediakan berbagai sumber daya informasi semata, melainkan perlu melihat relevansi koleksi yang dimilikinya dengan kebutuhan pengguna dan penyesuaian pelayanan dengan perubahanperubahan yang terjadi dilingkungannya. Oleh karena itu, pandangan perpustakaan perguruan tinggi tidak sekedar hanya "the library as the heart of the university" semata, melainkan mempertanyakan nilai apa yang dapat diberikan oleh perpustakaan kepada penggunanya. Jika dilihat dari keterangan tersebut, hakikat

\footnotetext{
${ }^{3}$ Indonesia, Departemen Pendidikan Nasional. 2004. Perpustakaan Perguruan Tinggi. Buku Pedoman. Jakarta: Direktorat Jendral Pendidikan Tinggi, hal 24.

${ }^{4}$ Ibid, Op. Cit, hal 6-7
}

perpustakaan adalah pusat sumber belajar dan sumber informasi belajar 5 .

Perpustakaan adalah sarana penunjang pendidikan berupa kumpulan bahan pustaka, baik berupa buku-buku maupun bukan buku. Kumpulan bahan pustaka tersebut diorganisasi secara sistematis dalam satu ruangan sehingga dapat membantu pemustaka dan para guru dalam proses pembelajaran. Sehingga, perpustakaan turut serta dalam menyukseskan pencapaian lembaga pendidikan yang menaunginya ${ }^{6}$. Adanya perpustakaan di lembaga pendidikan akan lebih memudahkan pendidik dan peserta didik dalam memperoleh kesempatan untuk memperdalam dan memperluas wawasannya dalam berbagai hal dengan cara membaca literatur-literatur atau bahan-bahan pustaka yang telah disediakan. Oleh karena itu, perpustakaan merupakan sarana penunjang pendidikan yang keberadaannya sangat dibutuhkan sebagai sumber belajar, serta mampu mewadahi dan mengembangkan minat baca peserta didik.

Selain memenuhi standar, perpustakaan perguruan tinggi harus mengikuti standar nasional pendidikan. Hal itu sangat terlihat pada saat akreditasi program studi (APS) dan akreditasi perguruan tinggi (APT), perpustakaan diminta untuk memenuhi berbagai standar berkaiatan dengan standar nasional pendidikan yang dituangkan menjadi standar oleh Badan Akreditasi Nasional Perguruan Tinggi (BAN-PT). beberapa standar yang penting dalam perpustakaan perguruan tinggi dan standar yang harus dipenuhi dalam mendukung akreditasi program studi adalah sebagai berikut: anggaran perpustakaan, gedung perpustakaan, koleksi perpustakaan, sumber daya manusia, akses internet, kunjungan layanan perpustakaan.

Membaca adalah salah satu media penyerapan ilmu pengetahuan dan informasi, karena kemampuan baca yang tinggi akan memacu seseorang untuk mengembangkan diri melalui penyerapan ilmu pengetahuan, teknologi dan budaya. Membaca juga merupakan kegiatan yang memberdayakan beberapa indra secara bersamaan, karena

\footnotetext{
${ }^{5}$ Darmono, Perpustakaan Sekolah: Pendekatan Aspek Manajemen dan Tata Kerja ( Jakarta :PT Grasindo, 2007), hlm2.

${ }^{6}$ Andi Prastowo, Manajemen Perpustakaan Sekolah Profesional, (Jogjakarta:DIVAPress, 2013), hlm 45.
} 
melalui membacalah maka ilmu dapat direkam lebih banyak dan lebih lama.

Penulis melihat penatalayanan di perpustakaan masih perlu dibenahi kembali. Berdasarkan pengamatan penulis di lapangan, bahwa anggaran perpustakaan, koleksi perpustakaan dan sumber daya manusia, akses internet, kunjungan layanan perpustakaan masih dibawah standar. Anggaran perpustakaan belum sampai 5 persen dari anggaran PT dan pengelolaannya tidak mandiri, koleksi buku masih belum memenuhi kebutuhan mahasiswa, tidak adanya ketersediaan Koran, majalah, jurnal tercetak dan online yang berlangganan, sumber daya manusia yang belum memenuhi standar, kebanyakan pegawai tidak memiliki etos kerja yang baik dan penempatan pegawai tidak karena kebutuhan namun karena unsure kepentingan, akses internet yang minim dan tidak dikelola dengan baik, sehingga computer dalam jumlah yang banyak tidak dapat digunakan dan pengelolanya tidak bekerja dengan baik bahkan sangat buruk, kunjungan sudah berkisar 50 persen dari jumlah mahasiswa, namun kunjungan dosen dan pegawai sangat minim. Hal ini berpengaruh terhadap minat baca pemustaka di perpustakaan IAKN Tarutung.

Berdasarkan latar belakang penulisan tersebut, peneliti tertarik untuk meneliti dan membuktikan kembali penelitian tentang pelayanan perpustakaan dan pengaruhnya terhadap tingkat kunjungan. Judul penelitian dari permasalahan yang diambil peneliti ialah : Pengaruh Penalayananan Perpustakaan Terhadap Tingkat Kunjngan Mahasiswa Semester IV T.A. 2017/2018 Prodi PAK IAKN Tarutung."

Berdasarkan uraian latar belakang masalah di atas, dapat dirumuskan pokok permasalahan seberapa besar pengaruh penatalayanan perpustakaan terhadap tingkat kunjungan mahasiswa semester IV T. A. 2017/2018 Prodi PAK IAKN Tarutung?

Tujuan penelitian berdasarkan rumusan masalah di atas, maka secara operasional tujuan yang akan dicapai dalam penelitian ini adalah untuk mengetahui seberapa besar pengaruh penatalayanan perpustakaan terhadap tingkat kunjungan mahasiswa semester IV T. A.

2017/2018 Prodi PAK IAKN Tarutung. Manfaat penelitian:

a. Manfaat teoritis. Hasil penelitian ini diharapkan dapat menambah pengetahuan dan informasi dalam bidang perpustakaan tentang pelayanan perpustakaan dalam rangka meningkatkan minat baca (tingkat kunjungan) mahasiswa.

b. Manfaat praktis. 1) bagi perguruan tinggi penelitian ini dapat memberikan informasi positif tentang pelayanan perpustakaan, sehingga dapat meningkatkan tingkat kunjungan mahasiswa. Penelitian ini juga dapat digunakan sebagai bahan evaluasi kinerja lembaga perguruan tinggi pada masa yang akan datang dengan lebih baik. 2) bagi pustakawan penelitian ini dapat memberikan masukan tentang pelayanan perpustakaan, sehingga pustakawan dapat memberikan pelayanan terbaik kepada mahasiswa. 3) bagi pemustaka pelayanan ini dapat menjadikan referensi bagi pemustaka untuk menambah wawaasan dan pengetahuan tentang kualitas pelayanan perpustakaan dan pengaruhnya terhadap tingkat kunjungan mahasiswa.

\section{PEMBAHASAN}

Perpustakaan berasal dari kata "pustaka". Arti pustaka adalah buku (Library dari bahasa Yunani). Perpustakaan dapat pula diartikan sebagai tempat kumpulan buku atau tempat buku dihimpun dan diorganisasikan sebagai media belajar. Sedangkan Wafford mengartikan perpustakaan sebagai salah satu organisasi sumber belajar yang mengelola, menyimpan dan memberikan layanan bahan pustaka baik buku maupun non buku kepada masyarakat tertentu maupun masyarakat umum. Lebih luas lagi pengertian perpustakaan adalah salah satu unit kerja yang berupa tempat untuk mengatur, mengelola, menyimpan dan mengumpulkan koleksi bahan pustaka secara sistematis untuk digunakan oleh pemakai sebagai sumber informasi sekaligus sebagai sarana belajar yang menyenangkan.

Menurut Sulistyo-Basuki perpustakaan ialah sebuah ruangan, bagian sebuah gedung itu sendiri yang digunakan untuk menyimpan buku dan terbitan lainnya yang biasa disimpan menurut tata susunan tertentu untuk digunakan pembaca, bukan untuk dijual. Dalam pengertian buku dan terbitan lainnya termasuk di dalamnya semua bahan cetak, buku, majalah, laporan, pamflet, prosiding, manuskrip (naskah),

7

http://www.pengertianahli.com/2014/04/pengertia n-perpustakaan-dan-fungsi.html. diunggah tgl 22 Agustus 2018 
lembaran music, berbagai karya music, berbagai karya media audiovisual seperti film, slid (slide), kaset, piringan hitam, bentuk mikro seperti microfilm, mikrofis, dan mikroburam (microopaque). Webster menyatakan bahwa perpustakaan merupakan kumpulan buku, manuskrip, bahan pustaka lainnya yang digunakan untuk keperluan studi atau bacaan, kenyamana atau kesenangan. ${ }^{8}$

$$
\text { Perpustakaan perguruan tinggi }
$$

merupakan salah satu sarana dalam melaksanakan program pendidikan dan penelitian yang dilaksanakan oleh perguruan tinggi yang menyelenggarakannya. Menurut Soedibyo perpustakaan perguruan tinggi adalah "suatu unit kerja yang merupakan bagian integral dari suatu lembaga induknya yang bersama-sama dengan unit lainnya tetapi peranan yang berbeda, bertugas membantu perguruan tinggi yang bersangkutan melaksanakan tri dharma. ${ }^{9}$

Fungsi perpustakaan dapat dilihat melalui beberapa uraian berikut ini: Fungsi informasi perpustakaan menyediakan berbagai jenis informasi yang meliputi bahan tercetak, terekam maupun koleksi lainnya agar pengguna perpustakaan dapat :

1. Mengambil berbagai ide dan buku yang ditulis oleh para ahli dan berbagai bidang ilmu.

2. Menumbuhkan rasa percaya diri dalam menyerap informasi dalam berbagai bidang serta mempunyai kesempatan untuk dapat memilih informasi yang layak yang sesuai dengan kebutuhannya.

3. Memperoleh kesempatan untuk mendapatkan berbagai informasi yang tersedia di perpustakaan dalam rangka mencapai tujuan yang diinginkan.

4. Memperoleh informasi yang tersedia diperpustkaan untuk memecahkan masalah yang dihadapi dalam kehidupan sehari-hari di masyarakat.

Sejalan dengan perkembangan ilmu pengetahuan, teknologi, komunikasi dan budaya serta peningkatan kebutuhan pemustaka maka fungsi PPT dikembangkan lebih rinci sebagai berikut:

8 Sulistyo-Basuki. 1991. Pengantar IImu Perpustakaan. Jakarta: Gramedia Pustaka Utama, halaman 3.

9 Soedibyo, Noerhayati. 1987. Pengelolaan Perpustakaan Jilid 2. Bandung : Alumni, hal 1.
1. Studying Center, artinya bahwa perpustakaan merupakan pusat belajar maksudnya dapat dipakai untuk menunjang belajar (mendapatkan informasi sesuai dengan kebutuhan dalam jenjang pendidikan).

2. Learning Center, artinya berfungsi sebagai pusat pembelajaran (tidak hanya belajar) maksudnya bahwa keberadaan perpustakaan difungsikan sebagai tempat untuk mendukung proses belajar mengajar. (Undang-undang No. 2 tahun 1989 Ps. 35 : Perpustakaan harus ada di setiap satuan pendidikan yang merupakan sumber belajar).

3. Research Center, hal ini dimaksudkan bahwa perpustakaan dapat dipergunakan sebagai pusat informasi untuk mendapatkan bahan atau data atau informasi untuk menunjang dalam melakukan penelitian.

4. Information Resources Center, maksudnya bahwa melalui perpustakaan segala macam dan jenis informasi dapat diperoleh karena fungsinya sebagai pusat sumber informasi.

5. Preservation of Knowledge Center, bahwa fungsi perpustakaan juga sebagai pusat pelestarian ilmu pengetahuan sebagai hasil karya dan tulisan bangsa yang disimpan baik sebagai koleksi deposit, local content atau grey literature.

6. Dissemination of information Center, bahwa fungsi perpustakaan tidak hanya mengumpulkan, pengolah, melayankan atau melestarikan namun juga berfungsi dalam menyebarluaskan atau mempromosikan informasi.

7. Dissemination of knowledge Center, bahwa disamping menyebarluaskan informasi perpustakaan juga berfungsi untuk menyebarluaskan pengetahuan (terutama untuk pengetahuan baru).

Layanan perpustakaan merupakan salah satu kegiatan utama di setiap perpustakaan. Bagian layanan berhubungan secara langsung dengan pemakai dan sekaligus merupakan barometer keberhasilan penyelenggaraan perpustakaan. Oleh karena itu dari meja layanan akan dikembangkan gambaran dan citra perpustkaan, sehingga seluruh kegiatan perpustakaan akan diarahkan dan terfokus kepada bagaimana memberikan layanan yang baik sebagaimana dikehendaki oleh masyarakat pemakai.

Layanan perpustakaan adalah seluruh kegiatan penyampaian bantuan kepada pemakai 
melalui berbagai fasilitas, aturan dan cara tertentu pada sebuah perpustakaan agar seluruh koleksi perpustakaan dapat dimanfaatkan semaksimal mungkin. Kualitas layanan berpusat pada upaya pemenuhan kebutuhan dan keinginan pemakai serta ketetapan penyampaian untuk mengimbangi harapan pemakai.

Faktor utama yang mempengaruhi pelayanan atau jasa adalah jasa yang diharapkan dan jasa yang diterima. Apabila jasa yang diterima konsumen sama dengan yang diharapkan atau bahkan lebih baik, maka dipersepsikan bahwa kualitas jasa tersebut baik atau positif dan demikian pula sebaliknya. Oleh karena itu, baik tidaknya kualitas jasa atau pelayanan sangat dipengaruhi oleh kemampuan dari penyedia jasa dalam memenuhi harapan konsumen secara konsisten.

Kualitas jasa sebagai ukuran seberapa bagus tingkat layanan yang diberikan mampu sesuai dengan ekspektasi pelanggan. Berdasarkan defenisi ini, kualitas pelayanan bisa diwujudkan melalui pemenuhan kebutuhan dan keinginan pelanggan serta ketetapan penyampaiannya untuk mengimbangi harapan pelanggan. Kualitas layanan harus dimulai dari kebutuhan pelanggan dan berakhir dengan kepuasan pelanggan serta persepsi positif terhadap kualitas pelayanan. Sebagai pihak yang mengkonsumsi jasa, pelanggan yang menilai tingkat kualitas jasa sebuah perusahaan. Sementara itu, persepsi dan interaksi dengan pelanggan dalam pemberian pelayanan juga ikut menentukan evaluasi kualitas pelayanan. Konsekquensinya jasa yang sama bisa dinilai berlainan oleh konsumen yang berbeda.

Di dalam perpustakaan kunjungan adalah faktor penentu keberhasilan perpustakaan. Seperti yang diketahui bahwa perpustakaan yang berhasil adalah perpustakaan yang dikunjungi oleh penggunanya. Jadi agar dapat dimanfaatkan dan dikunjungi dengan baik perpustakaan haruslah menyediakan fasilitas dan layanan yang baik kepada pengguna, misalnya dengan koleksi yang memadai dan mutakhir atau tidak ketinggalan zaman serta layanan yang baik pula. Pengguna perpustakaan pada umumnya berkunjung keperpustakaan karena memiliki tujuan. Namun, tentu saja tujuan tersebut tidak sama, akan tetapi kebanyakan pengguna perpustakaan mengunjungi perpustakaan karena ingin memanfaatkan koleksi dan layanan yang tersedia diperpustakaan.
Dalam penelitian ini, ada beberapa faktor yang mempengaruhi kepuasan konsumen yaitu tangible, reliability, responsiveness, assurance, dan empathy. Untuk mengetahui hubungan antara variable independen dengan variable dependen, maka akan dijelaskan sebagai berikut: Faktor tangible atau bukti fisik merupakan unsure penting untuk mengukur pelayanan, hal ini karena pelayana merupakan hal yang tidak berwujud sehingga tidak bisa disentuh. Tangible atau keberwujudan adalah penampilan fasilitas fisik, peralatan, personil dan perlengkapan komunikasi. Dimensi tangible ini umumnya digunakan untuk menaikan image di mata konsumen. Penampilan dan kemampuan sarana dan prasarana fisik harus dapat diandalkan, keadaan lingkungan sekitarnya adalah bukti nyata dari pelayanan yang diberikan oleh pemberi jasa. Penampilan fisik pelayanan, karyawan dan komunikasi akan memberikan warna tersendiri dalam pelayanan pemustaka.

Pengaruh tangible atau bukti fisik untuk melaksanakan pelayanan yang semestinya secara tepat. Keandalan berkaitan dengan probabilitas atau kemungkinan suatu produk melaksanakan fungsinya secara berhasil dalam periode waktu tertentu di bawah kondisi tertentu dengan demikian keandalan merupakan karakteristik yang merefleksikan kemungkinan atau probabilitas tingkat keberhasilan dalam penggunaannya.

Pengaruh reliability terhadap kepuasan mahasiswa adalah keandalan mempunyai pengaruh positif terhadap kepuasan mahasiswa. Semakin tinggi tingkat keandalan semakin tinggi pula kualitas layanan yang diterima oleh mahasiswa. Namun sebaliknya, semakin rendah tingkat keandalan semakin tinggi pula tingkat keandalan yang diterima mahasiswa, maka kepuasan mahasiswa pun rendah.

Pengaruh responsiveness atau ketanggapan adalah semakin tinggi tingkat ketanggapan, semakin tinggi pula kualitas layanan yang diterima oleh mahasiswa. Namun sebaliknya, semakin rendah tingkat keandalan yang diberikan maka tingkat kepuasan mahasiswa juga semakin rendah.

Pengaruh emphaty atau empati pada kepuasan mahasiswa adalah semakin tinggi empati maka semakin tinggi pula kualitas layanan yang diterima mahasiswa. Namun sebaliknya, semakin rendah empati yang diberikan kepada pelanggan, maka kepuasan mahasiswa pun akan rendah. 
Pengaruh assurance atau jaminan kepada kepuasan mahasiswa adalah semakin tinggi jaminan semakin tinggi pula kualitas layanan yang diterima mahasiswa. Namun sebaliknya jika jaminann yang diberikan mahasiswa rendah, maka akan timbul ketidak puasan mahasiswa atas dasar penjelasan tersebut.

Lima dimensi kualitas layanan seperti diatas dapat dikatergorikan ke dalam empat dimensi kualitas layanan tersebut, yaitu: jaminan kepada kepuasan mahasiswa adalah semakin tinggi jaminan semakin tinggi pula kualitas layanan yang diterima mahasiswa. Namun sebaliknya jika jaminann yang diberikan mahasiswa rendah, maka akan timbul ketidak puasan mahasiswa atas dasar penjelasan tersebut.

Lima dimensi kualitas layanan seperti diatas dapat dikatergorikan ke dalam empat dimensi kualitas layanan tersebut, yaitu:

1. Affect of service : merupakan penilaian terhadap aspek/ sisi manusia dari organisasi perpustakaan. Dimensi ini meliputi sikap empati, aksesibilitas dan kompetensi personal para pustakawan.

2. Personal control : dimensi ini terkait dengan mampu tidaknya pemakai untuk dapat mencari dan mengontrol dunia informasi yang disediakan tanpa bantuan pustakawan/ petugas perpustakaan. Bagaimana pemakai dapat melakukan aktivitas diperpustakaan dan memanfaatkan fasilitas di perpustakaan sendiri tanpa meminta bantuan pustakawan, petugas perpustakaan.

3. Acsess to information : dimensi ini menilai kecukupan koleksi yang dimiliki perpustakaan dan tingkat kemampuan dalam mengakses informasi yang dibutuhkan berdasarkan lama waktu untuk dapat memperolehnya.

4. Library as place : dimensi ini menyangkut penilaian perpustakaan oleh pemakai dalam pengertian fisik. Perpustakaan dinilai dari segi fungsional ruangan untuk kegiatan belajar, tanpa berkontemplasi dan refleksi diri atau peningkatan pertumbuhan pikiran.

Besar presantase kontribusi atau pengaruh variabel layanan perpustakaan terhadap tingkat kunjungan mahasiswa atau yang disebut koefisien determinasi (KD) R. Square sebesar 0,240 seperti yang terlihat pada tabel yang dibawah ini:

Tabel Uji Regresi

\begin{tabular}{|c|c|c|c|c|}
\hline \multicolumn{5}{|c|}{ Model Summary } \\
\hline Mode & R & R. & Adjuste & Std. \\
\hline
\end{tabular}

\begin{tabular}{|c|c|c|c|c|}
\hline 1 & & Square & $\begin{array}{c}\mathrm{d} \mathrm{R} \\
\text { Square }\end{array}$ & $\begin{array}{c}\text { Error of } \\
\text { the } \\
\text { Estimat } \mathrm{e}\end{array}$ \\
\hline 1 & $\begin{array}{c}49 \\
0^{\mathrm{a}}\end{array}$ & 240 & 230 & $\begin{array}{c}4.6493 \\
0\end{array}$ \\
\hline
\end{tabular}

a. prediktors: (konstan), layanan perpustakaan

Tabel tersebut menunjukkan bahwa kontribusi layanan perpustakaan terhadap tingkat kunjungan mahasiswa sebesar $24 \%$ sisanya sebesar $76 \%$ dipengaruhi oleh faktor lain.

Uji Signifikan $X_{1}$ Terhadap Variabel $Y$

Tabel Anova

\begin{tabular}{|c|c|c|c|c|c|c|}
\hline \multicolumn{7}{|c|}{ Anova* } \\
\hline Model & $\begin{array}{c}\text { Sum } \\
\text { of } \\
\text { Squar } \\
\text { es }\end{array}$ & $\begin{array}{c}\text { D } \\
\text { f }\end{array}$ & $\begin{array}{c}\text { Mea } \\
\text { n } \\
\text { Squa } \\
\text { re }\end{array}$ & F & Sig & \\
\hline \multirow{2}{*}{1} & Regressi & 492. & 1 & 492. & 22.7 & .00 \\
& on & 366 & & 366 & 78 & $0^{\text {b }}$ \\
\cline { 2 - 7 } & Residual & 1556. & 7 & 21. & & \\
& 350 & 2 & 616 & & \\
\hline & Total & 2048. & 7 & & & \\
& 716 & 3 & & & \\
\hline \multicolumn{7}{|c|}{ a. Dependent Variabel : Tingkat Kunjungan } \\
\hline \multicolumn{7}{|c|}{ b. Predictors : (Constant). Layanan } \\
\hline \multicolumn{7}{|c|}{ Perpustakaan } \\
\hline
\end{tabular}

Pada bagian ini menjelaskan apakah ada pengaruh yang nyata (signifikan) layanan perpustakaan terhadap tingkat kunjungan mahasiswa. Dari output uji Anova atau Ftes, didapat tes hitung adalah 22,778 dengan tingkat signifikan $0,000^{\mathrm{b}}<0,05$ karena probabilitas $(0,000)<0,005$, artinya ada pengaruh yang positif dan signifikan antara variabel layanan perpustakaan terhadap tingkat kunjungan

Hasil penelitian menunjukkan :

Terdapat hubungan positif yang signifikan antara penatalayanan perpustakaandengan tingkat kunjungan mahasiswa STAKNP Tarutung. Hal ini ditunjukkan oleh hubungan (korelasi) kategori cukup. Hal ini juga berarti jika penatalayanan perpustakaan ditingkatkan maka tingkat kunjungan mahasiswa di perpustakaan IAKN Tarutung akan meningkat. Hasil uji output korelasi di atas terdapat angka 0, 490, angka tersebut merupakan angka koefisien korelasi atau nilai $r$, sedangkan nilai $r$ tabel sampel 74 orang adalah 0,227 pada taraf signifikan 0,05. Hal ini menunjukkan bahwa nilai $r$ hitung lebih besar dari $r$ tabel, yang 
berarti ada hubungan yang positif dan signifikan antara penatalayanan perpustakaan dengan tingkat kunjungan pengunjung di perpustakaan IAKN Tarutung. Untuk mengetahui besarnya sumbangan atau kontribusi penatalayanan perpustakaan terhadap tingkat kunjungan mahasiswa di perpustakaan IAKN Tarutung sebesar 0,240.

Hal ini berarti bahwa sumbangan layanan perpustakaan terhadap tingkat kunjungan sebesar $24 \%$ dan sisanya sebesar $76 \%$ berasal dari faktor lain.

Dari hasil uji Anova didapat $\mathrm{f}$ hitung adalah 22, 778 dengan tingkat signifikan $0,000^{\mathrm{b}}<$ 0,05 karena probabilitas $(0,000)<0,05$, artinya ada pengaruh yang positif dan signifikan antara variabel layanan perpustakaan terhadap tingkat kunjungan mahasiswa.

\section{Simpulan}

Berdasarkan hasil pengujian hipotesis dapat dibuat kesimpulan sebagai berikut:

1. Terdapat hubungan postif yang sgnifikan antara layanan perpustakaan terhadap tingkat kunjungan mahasiswa. Nilai korelasi antara layanan perpustakaan (X) dengan tingkat kunjungan mahasiswa IAKN Tarutung kategori cukup.

2. Sumbangan atau kontribusi layanan perpustakaan terhadap tingkat kunjungan sebesar $24 \%$ dan sisanya sebesarnya $76 \%$ berasal dari faktor lain.

3. Dari output uji anova atau F test, dapat F dihitung adalah 22,778 dengan tingkat signifikan $0,000^{\mathrm{b}}<0,05$. Karena probabilitas $(0,000)$ lebih kecil dari 0,05 , artinya ada Pengaruh Layanan Perpustakaan Terhadap Tingkat Kunjungan Mahasiswa IAKN Tarutung. S

4. Skor Layanan Perpustakaan maupun skor tingkat kunjungan mahasiswa kategori sedang atau cukup. Hal ini berarti layanan perpustakaan di IAKN Tarutung Cukup Baik, dan mahasiswa sebagai pengunjung merasa cukup puas terhadap layanan yang diberikan oleh perpustakaan IAKN Tarutung.

Berdasarkan hasil penelitian yang dilakukan penulis maka penulis memberikan saran sebagai berikut:

1. Hasil Penelitian ini memperlihatkan bahwa mahasiswa IAKN Tarutung memandang kualitas pelayanan dalam taraf sedang atau cukup. Oleh karena itu perpustakaan dapat meningkatkan halhal yang terkait dengan layanan yang sesuai dengan apa yang mahasiswa harapkan.

2. Berdasarkan peraturan koleksi buku yang ada di IAKN Tarutung belum memenuhi kebutuhan mahasisw, diharapkan untuk menambahi koleksi buku yang berkaitan dengan Prodi masing-masing. Dengan bertambahnya buku diharapkan kepuasan dan tingkat kunjungan mahasiswa akan lebih meningkat.

3. Untuk meningkatkan penatalayanan diharapkan untuk melakukan survey secara berkala agar bisa melihat gambaran perkembangan dan pelayanan yang lebih baik bagi pengunjung.

\section{DAFTAR PUSTAKA}

1. Basuki Sulistyo, Pengantar Ilmu Perpustakaan (Jakarta: Gramedia Pustaka Utama, 1991)

2. Darmono, Perpustakaan Sekolah: Pendekatan Aspek Manajemen dan Tata Kerja ( Jakarta : PT Grasindo, 2007)

3. Departemen Pendidikan Nasional Perpustakaan Perguruan Tinggi. Buku Pedoman (Jakarta: Direktorat Jendral Pendidikan Tinggi, 2004)

4. Noerhayati Soedibyo, Pengelolaan Perpustakaan Jilid 2 (Bandung : Alumni, 1987)

5. Prastowo Andi, Manajemen Perpustakaan Sekolah Profesional (Jogjakarta: DIVA Press, 2013)

6. Sutarno Ns, Perpustakaan dan Masyarakat, (Jakarta: CV. Sagung Seto, 2006)

7. R. E. Allen, The Pocket Oxford Dictionary of Current English (Oxford: Clarendon Press, 1984)

8. Undang-undang Republik Indonesia Nomor 43 Tahun 2007 
9. http://www.pengertianahli.com/2014/04 /pen gertian-perpustakaan-dan-fungsi.ht 